\title{
ТЕАТРАЛІЗОВАНІ ТАНЦЮВАЛЬНІ ШОУ (ШОУ-ПРОГРАМИ) В ІНДУСТРІї РОЗВАГ
}

У статті розглянуто проблематику розвитку театралізованих танц̧ювальних шоуяк відносно нове дослідницьке питання для вітчизняної мистецтвознавчої науки. Визначено специифічні особливості сучасного танцюю й танцуювального шоу. Проаналізовано роль науково-технічного прогресу у вдосконаленні виконання шоу. Виявлено співвідношення сучасного і традииійного (фольклорного) у театралізованих танцюювальних шоу. Досліджено 5 обраних шоу-програм України, США, Росії, Ірландї й Туреччини.

Ключові слова: театралізовані танцюювальні шоу, танець, шоу-програми, індустрія розваг, мистецтвознавство, стиль, фольклор, міфологія, балетмейстер, технічні засоби.

В статье рассмотрена проблематика развития театрализованных танцевальных шоу как относительно новый исследовательский вопрос для отечественной искусствоведческой науки. Определены специифические особенности современного танца и таниевального шоу. Проанализирована роль научнотехнического прогресса в усовершенствовании исполнения шоу. Выявлено соотношение современного и традиционного (фольклорного) в театрализованных танцевальных шоу. Исследованы 5 избранных шоу-программ Украины, США, России, Ирландии и Туричии.

Ключевые слова: театрализированные танцевальные шоу, танец, шоупрограммы, индустрия развлечений, искусствоведение, стиль, фольклор, мифология, балетмейстер, технические средства.

In the article the problem of development of the theatricalized dancing shows is considered as relatively new research question for domestic study of art science. The specific features of modern dance and dancing show are certain. The role of scientific and technical progress is analyzed in the improvement of execution of show. Correlation is exposed modern and traditional (folk-lore) in the theatricalized dancing shows. 5 select shows-programs of Ukraine, USA, Russia, Ireland and Turkey are investigational.

Key words: theatricalized dancing shows, dance, shows-programs, industry of entertainments, study of art, style, folk-lore, mythology, ballet-master, hardware.

Вагоме місце у сфері культурно-мистецького життя сучасної людини займають численні театралізовані дійства. Театралізоване шоу - один із видів культурнодозвіллєвої роботи й активності, якому властиві наявність усіх театральних ефектів: світло, музика, костюми тощо. Мова йде про шоу-програми або костюмовані розважальні програми, що мають тематичний сценарний хід. 
Танцювальні театралізовані шоу мають значну світову популярність, що вже само по собі визначає актуальність їх наукового дослідження з метою систематизації відомостей про види цих шоу, їх класифікацію, виокремлення специфічних національних рис тощо. Очевидно, що розвиток таких шоу як на міжнародному рівні, так і в окремо взятій країні безумовно пов'язаний з еклектикою стилів і напрямів, супроводжується постійним творчим пошуком і експериментаторством. Специфічною рисою індустрії цих шоу у нашій країні є пов'язаність постмодерністських тенденцій та українського національного колориту (традиційного танцю).

Існує істотний зв’язок даної дослідницької проблеми із важливими науковими та практичними завданнями. Проблематика дослідження театралізованих танцювальних шоу (шоу-програм) знаходиться на перехресті кількох гуманітарних дисциплін, насамперед мистецтвознавства, теорії культури й історії культури, а також театрального мистецтва.

Попри те, що у цілому розвиток шоу-бізнесу став об' єктом дослідження цілого ряду дисертаційних праць, монографій і посібників $[3 ; 7 ; 12 ; 14 ; 16]$, вивчення театралізованих танцювальних шоу є відносно новою проблематикою для вітчизняної науки. Серед фахових дослідників масових театралізованих заходів в Україні слід назвати лише деяких окремих авторів наукових праць (А. Горбова, О. Кужельного (Київ) [6; 10], А. Житницького (Харків) [8; 9], Л. Сєрих (Суми) [15]), а також публікацій (викладачів Київського національного університету культури і мистецтв М. Мельник [11], М. Татаренко [17] й інших учених).

Виходячи із вказаного, метою статті є спроба окреслити особливості наявного розвитку театралізованих танцювальних шоу (шоу-програм) в індустрії розваг.

Для розуміння сутності театралізованих танцювальних шоу важливим є визначення специфічних особливостей саме сучасного танцю. Як стверджує Ю. Басич, «сучасний танець - це танцювальний напрямок, що синтезує у собі різноманітні стилі. У ньому репрезентовані елементи класичного танцю, модерн-балету, джаз-танцю, хіп-хопу, фанку тощо» [5, с. 28]. Можна у повній мірі погодитися із дослідником стосовно того, що значну роль у сучасних танцювальних шоу відіграють як фольклорні мотиви (національна символіка й ритміка), так і елементи «вуличного танцю» (взяті, насамперед, із США) $[5$, c. 28,29$]$. Водночас може вважатися дискусійною теза науковця про те, що «триває плідний процес взаємообміну української хореографічної культури з арабською,

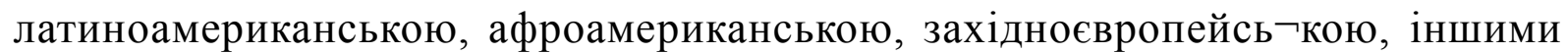
культурами» [5, с. 28, 29]. На нашу думку, українські танцювальні шоу, крім власне національних елементів, беруть за зразок все ж, насамперед, європейські, а не латиночи афроамериканські традиції.

М. Татаренко наголошує на істотному зв'язку театралізованих шоу із міфологічним началом у світогляді людини. При цьому стверджується, що «походження видовища тісно пов'язане з первісними ритуалами та міфологічними уявленнями про світ. Ритуальна форма, насичена міфологічним змістом, склала суть видовища і дала йому поштовх для подальшого розвитку» [17, с. 300]. Водночас дослідниця вказує на важливій ролі балетмейстерів, що забезпечують професійне виконання масових видовищних заходів різних форматів, у т. ч. й театрального [17, с. 301]. Зазначене $\epsilon$ 
необхідним як у випадку використання у шоу окремих елементів театралізованого дійства, так і в разі повністю театралізованої специфікації видовища. Адже в багатьох випадках у таких шоу беруть участь особи із різною хореографічною підготовкою, що вимагає необхідних навчаючих і координуючих дій досвідчених фахівців [17, с. 302].

Потужним стимулом для удосконалення театралізованих видовищ упродовж останніх десятиліть виявився науково-технічний прогрес, наслідком інтенсифікації якого став надзвичайно швидкий розвиток технічних засобів для сцени (світло, звук, різноманітні спецефекти, лазерні проекції тощо). Крім того, фактором підтримки розширення індустрії розваг у вигляді театралізованих дійств $є$ масштабні міжнародні заходи, в т. ч. спортивні - наприклад Олімпіади, чемпіонати світу з футболу тощо.

За оцінкою М. Мельник, «театралізований тематичний концерт - це актуальна гра, «живе» виконання, така форма концертного дійства може проводитися на будь-яких майданчиках: у концертних палацах, на стадіонах, галявинах, площах, майданах, у парках» $[11$, с. 95]. При цьому цілком слушно стверджується, що «саме театралізовані тематичні концерти дозволяють об'єднати маси людей на підставі єдиних культурних цінностей» $[11$, с. 96]. Для театралізованих дійств «характерне використання всіх засобів театрального мистецтва: слова, музики, хореографії, світла, темпоритму, мізансцени, сценографії, шумового оформлення, піротехнічних засобів тощо... Саме режисер театралізованого тематичного концерту - це той художник-творець, який повинен мати особисту позицію, що визначає його творче обличчя, володіти універсальними знаннями і навичками, яких вимагає специфіка естрадної постановки» [11, с. 98].

Підсумовуючи наявні концепції розвитку театралізованих шоу, варто зазначити, що сучасна людина із кожним роком висуває все більш високі вимоги до якості театралізованих танцювальних шоу. Вимогливий глядач очікує від кожного шоу вишуканих методів виконання, залучення сучасної техніки звукопідсилення й звукозапису, а також піротехніки, лазерів і світлової апаратури.

Переходячи до практичного розгляду окремих театралізованих танцювальних шоу слід зупинитися на таких із них: програма Алли Духової («Тодес») «Танцюємо любов», «Lord of the dance», «Burn The Floor», спектакль «Сильніше страсті, більше, ніж любов...» балету А6, танцювальні шоу «Вогні Анатолії» / «Троя».

1) Програма Алли Духової («Тодес») «Танцюємо любов»

Балет Алли Духової «Тодес» є унікальним, як за талантом і натхненням, так і за працьовитістю й професіоналізмом. Він став фактичним піонером шоу-балетного руху в Росії. Власне А. Духова була не лише балетмейстером, постановником і творцем, але й найважливішим ідейним натхненником і художнім керівником «Тодеса». Усі номери, що поставлені Аллою, завжди пронизані особистим ставленням, почуттями, емоціями, де знайомі кожному людські ситуації знаходять пластичне втілення, переломлюючи почуття мовою танцю. На переконання А. Духової, про любов не говорять, про неї танцюють, і кожна «love story» може знайти втілення у танці.

У 2007 р. трупа балету «Тодес» показала нову театралізовану програму «Танцюємо любов». Глядачів очікували феєрія звуку, унікальні світлові рішення, оригінальні костюми, драматичні колізії та, звичайно, фірмова динамічна хореографія від художнього керівника трупи А. Духової. 
«Танцюємо любов» є історією відносин двох молодих людей, які прагнуть знайти себе у великому місті й реалізувати власний творчий потенціал, не зруйнувавши при цьому свою любов. А. Духова при створенні шоу вважала, що абсолютно неважливо, в якому стилі людина танцює - класичному або сучасному, адже мовою тіла можна передати без слів будь-які відтінки емоцій, і всім буде зрозуміло, про що людина танцює і що прагне висловити. Адже найбільш видатні сучасні танцівниці, наприклад П. Бауш, були універсалами і могла станцювати абсолютно все. 3 іншого боку, сучасний балет більше відповідає духу часу: він різноманітний, постійно змінюється, поєднує нові тенденції. 3 огляду на вказане, і шоу «Танцюємо любов» як «contemporary dance» колинебудь увійде в історію і стане класикою [1].

2) «Lord of the dance»

«Lord of the Dance» («Володар Танцю» чи «Король Танцю») - ірландське танцювальне шоу, поставлене хореографом М. Флетлі у 1996 р. Автором саундтреку $є$ Р. Хардіман. Сюжетне шоу, що базується на кельтській фолк-музиці й ірландських народних танцях, завоювало широку популярність. Трупа неодноразово здійснювала тури по Свропі й США. Було продано 9 млн. відеозаписів і 1,2 млн. аудіодисків із саундтрекім «Lord of the Dance».

Відомий ірландський танцюрист і хореограф М. Флетлі покинув шоу «Riverdance» у 1995 р., заснувавши власну продюсерську компанію «Unicorn Entertainments ltd» і за півроку склавши концепцію нової танцювальної вистави, яка планувалася для виконання на великих аренах. Уперше шоу «Lord of the Dance» було представлено публіці у Дубліні 28 червня 1996 р. Крім танцювальних номерів, у «Lord of the Dance» були присутні суто інструментальні («дуель скрипок») і кілька пісень. Деякі номери виконувалися без музичного супроводу.

«Lord of the Dance» на момент своєї прем'єри став самим успішним танцювальним шоу, провівши аншлагові тури по Свропі й США. У 1998 р. на базі «Lord of the Dance» M. Флетлі створив нове, розширене шоу «Feet of Flames», куди увійшла значна частина номерів «Lord of the Dance».

Наразі існують дві трупи, що виступають із класичною версією «Lord of the Dance» без участі М. Флетлі. Перший склад трупи (основний) періодично гастролює по країнах Свропи, другий склад постійно виступає в країнах Північної Америки.

Номери «Lord of the Dance» об'єднані сюжетом, що представляють собою легенду в стилі фентезі, яка частково базується на сильно узагальнених ірландських легендах. У шоу не передбачено діалогів і сюжет доноситься у вигляді інтуїтивно зрозумілих сцен, жестів і рухів персонажів, музики й танцю. Частина інформації повідомляється у проміжних піснях ірландською мовою (у європейському турі 2010 р. - англійською) [13].

3) «Burn The Floor»

Музично-танцювальне шоу «Burn the Floor», в якому беруть участь одні 3 найкращих різножанрових танцювальних колективів США, одержало величезну популярність і гучні позитивні рецензії по усьому світу за свою енергетику, професіоналізм і пристрасть. Шоу піднімає бальні танці на нову висоту, створюючи грандіозне танцювальне видовище нового тисячоріччя. Молоді зірки Бродвею приїжджають у складі гастрольної трупи з танцювальним шоу, яке вже кілька років 3 успіхом іде у бродвейському «Longacre Theatre». 
Шоу-спектакль «Burn the floon» був придуманий і поставлений на сцені Джейсоном Гілкісоном, екс-чемпіоном світу з латинських і бальних танців. У шоу, крім зірок А. Гарніс і О. Ковальова, беруть участь 18 багаторазових переможців різних танцювальних конкурсів із США, Великобританії, Італії, Австралії, Малайзії, Венесуели й Росії. Це такі діячі як К. Хауер, Ш. Бургесс, С. Фарбер, Д. Гарнер, С. Хайвс, П. Хелм, А. Хантер, К. Стумпфова, Г. Райт, А. Чігвінцев, М. Хупер, Е. Слейтер, С. Коста, М. Ціолан, Н. Санталуція, Д. і Р. Сугден і Р.Виндзор. Зокрема, жіночий вокал у виконанні Р. Тапії відігравав роль Габріели у популярному «High School Musical».

Критики усього світу, не змовляючись, називають спектакль «Burn the floor» видовищною й динамічною сенсацією. Це фактично спектакль про танець, що увібрав у себе всю історію цього мистецтва, від чарльстону й фокстроту до румби й сальси. Зокрема, у рамках одного шоу були об'єднані віденський вальс, танго й свінг [2].

4) Спектакль «Сильніше страсті, більше, ніж любов...» балету А6

Спектакль «Сильніше страсті, більше, ніж любов...» київського балету А6 мав свою прем’єру ще в 2007 році. Зазначений творчий колектив (наразі це арт-компанія) був утворений у столиці нашої держави в сер. 1990-х рр. Артисти колективу регулярно беруть участь у створенні кліпів і концертних програм для вітчизняних і закордонних виконавців. В основі проекту «Сильніше страсті, більше, ніж любов...»-стиль танго у найрізноманітніших його варіантах, у т. ч. в стилі «besame mucho». Театралізована хореографічна вистава супроводжується яскравим шоу й спецефектами. Загальні тони шоу - червоно-чорні, складові шоу - кілька номерів популярного стилю танцю, що представляють національну культуру окремих народів (кан-кан, сиртакі, кантрі).

Ідейним натхненником і постановником спектаклю, художнім керівником балету «А6» є Ганна Азарова. На їі думку, ключем у назві спектаклю «Сильніше страсті, більше, ніж любов...» може бути тільки саме життя, так що по суті зазначене шоу - це ода життя з усіма ії злетами, падіннями й самими неймовірними ситуаціями. Любовний трикутник, ревнощі, самітність, закоханість, весілля, поява дитини - таким сильним емоціям потрібно було дати вихід і арт-компанія «Аб» увібрала все це у вигляді художньої форми й поставили спектакль.

В арт-компанії «А6» переконані, що навчити танцювати можна практично будьякої людину. Водночас далеко не кожному індивіду буде притаманний магнетизм, глибина й здатність подарувати одкровення.

Ключовим видовищним фактором шоу «Сильніше страсті, більше, ніж любов...» $\epsilon$ синхронність, що представляється не просто технічністю, а професіоналізмом, здатністю колективу перетворюватися на підмостках у єдиний організм.

Наразі шоу-балет «А6»- це постійні учасники грандіозних заходів і концертів, що відбуваються не лише в Україні, але й далеко за їі межами. За роки свого існування «А6» підготували велику кількість концертних програм, супроводжували виступи й брали участь у створенні кліпів популярних вітчизняних і закордонних виконавців; гастролюють як по Україні, так і закордоном, готують танцюристів-професіоналів. Представники балету «А6» є режисерами-хореографам кількох десятків танцювальних шоу-програм у різних містах і країнах світу [19].

5) Танцювальні шоу «Вогні Анатолії» / «Троя»

Одним із елементів позитивного туристичного і культурного іміджу Туреччини $\epsilon$ захоплюючі сучасні шоу «Вогні Анатолії» й «Троя», які являються музичною й 
танцювальною інтерпретацією історичного процесу розвитку регіону Анатолія у Малій Азії. «Вогні Анатолії - це синтез сучасної хореографії, народного танцю й класичного балету. У процесі перегляду глядачі бачать гіпнотичне крутіння дервішів, танець лезгинку, ритмічний халай та інші східні танці. У процесі шоу показується зародження й розвиток культурного спадку регіону, що поєднав у собі безліч етносів і цивілізацій - зниклих хетів, тюркських кочівників, грецьких і римських держав, а також самобутньої турецької культури, що сполучили елементи традицій сельджуків і османів. Це шоу свого часу показувалося у «Gloria Aspendos Arena» неподалік від населеного пункту Аспендос на середземноморському узбережжі Туреччини.

У свою чергу, шоу «Троя» $є$ танцювальною й музичною варіацією знаменитої поеми Гомера, створеної ще у 1180 до н. е. Це шоу, як і «Вогні Анатолії», показувалося у «Gloria Aspendos Arena» в Туреччині. Крім того, театральна трупа демонструє шоу «Врата Сходу» про історію найдавнішого міста Турецького Закавказзя Ерзурум (колишній центр безлічі різноманітних культур).

Перші вистави програм «Вогні Анатолії» і «Троя» були показані в 2001 р. 3 тих пір шоу подивилися понад 20 млн глядачів у більш ніж 85 країнах світу. Артисти виступали на арені Медісон Сквер Гарден у Нью Йорку, Конкурсі Свробачення й відкритті Універсіади, етапі гонок Формула-1 і перед пірамідами Сгипту. Шоу «Вогні Анатолії» давно потрапило у книгу рекордів Гінесса за найбільшу аудиторію й виконання танців 3 більш ніж 200 па за одну хвилину.

До складу трупи входить понад 250 артистів, що дає можливість проведення одночасно трьох концертів із рівнозначним рівнем якості сольної й групової танцювальної підготовки виконавців, декорацій, костюмів, аудіо- й візуального супроводу.

У 2008 р. для виступу колективу групи «Вогні Анатолії» був побудований новий сценічний майданчик «Gloria Aspendos Arena», розташований приблизно в одному кілометрі від старого театру. Попри те, що акустика у залі мало чим відрізняється від сучасних сценічних майданчиків, наразі шоу «Вогні Анатолії» дещо втратило у контексті особливої аури єднання артистів і глядачів. Станом на сер. 2016 р. шоу починається о 20.00 і завершується о 23.00. Кожне із двох відділень триває близько однієї години [18].

Підсумовуючи вищевказане, ми прийшли до наступних висновків у контексті проблематики даного дослідження:

- сучасні театралізовані танцювальні шоу характеризуються масштабністю події, масовістю, образністю, видовищністю. При цьому глядач не лише переглядає шоу, а де-факто стає його співучасником;

-потужним стимулом для вдосконалення театралізованих видовищ упродовж останніх десятиліть виявився науково-технічний прогрес, наслідком інтенсифікації якого став надзвичайно швидкий розвиток технічних засобів для сцени. Вагому роль тут відіграли, зокрема, багатотисячні міжнародні заходи, ут. ч. спортивні;

-щороку збільшується рівень вимог, котрі висуває сучасний глядач до якості театралізованих танцювальних шоу. Спільними рисами розглянутих у межах даної статті шоу-програм (України, США, Росії, Ірландії й Туреччини) є такі: преміальний, але водночас масовий і вельми видовищний характер, поєднання постмодерних і класичних елементів, наявність талановитого постановника і хореографа. Водночас між різними 
національними шоу-програмами існують і відмінні риси: використання різних стилів, відмінна тематика дійств (почуття людей, політика, історія тощо), кількість професійних виконавців (від кількох осіб до кількох сотень осіб).

Перспективним напрямом дослідження, на нашу думку, можна вважати аналіз іншомовної фахової літератури з проблематики театралізованих танцювальних шоу, в т. ч. для проведення компаративного аналізу вітчизняних і зарубіжних науководослідницьких і практичних підходів до шоу-програм.

\section{Jimepamypa:}

1. Духова А. Таниуем любовь / А. Духова : [Электронный ресурс]. - Режим доступа: http://eclectic-magazine.ru/alla-duxova-tancuem-lyubov. 2. Гарнис A. В бродвейском танцевальном шоу Burn the floor / A. Гарнис : [Электронный ресурс]. - Режим доступа: http://vancouverandus.com/?p=854. 3. Афанасьєва К. О. Захист інтелектуальної власності в шоу-бізнесі / К. О. Афанасьєва. - Київ : ВАІТЕ, 2009. - 256 с. 4. Балет Алль Духовой «TODES». Спектакль «Таниуем любовь» [Электронный ресурс]. - Режим доступа: https://www.ticketland.ru/teatry/teatr-ally-dukhovoy-todes/tancuem-lyubov. 5. Басич Ю. М. Сучасний танещь та місие традиџійної танщювальної символіки в украӥнськійхореографії/ Ю. М. Басич // Філософія і політологія в контексті сучасної культури. - 2014. - Вип. 7. С. 26-31. 6. Горбов А. Постановка видовищно-театралізованих заходів / А. Горбов; упоряд. О. Колонькова. - К. : Шкільний світ, 2010. - 127 с. 7. Данчук Л. І. Азбука режсисури шоупрограм / Л. І. Данчук. - Житомир : Полісся, 2008. - 288 с. 8. Драматургія масових театралізованих заходів / Авт.-уклад. А. 3. Житницький ; Харківська держ. академія культури. - Харків : ХДАК, 2004. - 128 с. 9. Житницький А. З. Драматургія масових театралізованих заходів / А. 3. Житницький. - Харків : Тимченко А. М., 2005. - 128 с. 10. Кужельний О. П. Основи режисури театралізованих видовищ і свят / О. П. Кужельний; Нац. акад. кер. кадрів культури і мистец. - Київ : НАКККіМ, 2012. - 140 с. 11. Мельник М. М. Сучасний стан і тендениії розвитку театралізованого тематичного концерту / М. М. Мельник// Мистецтвознавчі записки. -2012. - Вип. 21. - С. 95-101. 12. Москаленко К. В. Продюсерський договір в сфері музичного шоу-бізнесу: ичвільно-правові аспекти : автореф. дис. ... канд. юрид. наук : 12.00 .03 / Москаленко Катерина Вікторівна ; Київ. наи. ун-т ім. Тараса Шевченка. - Київ, 2014. - 20 c. 13. Oфіиійний сайт Lord of the Dance [Електронний ресурс]. - Режим доступy: http://www.lordofthedance.com. 14. Поплавський М. М. Шоу-бізнес: теорія, історія, практика / М. М. Поплавський. - Київ : Видав. Центр КНУКіМ, 2001. - 560 с. 15. Сєрих Л. В. Формування естетичної культури молодших школярів у прочесі театралізованої діяльності : монографія / Л. Сєрих ; Iн-т пробл. виховання АПН України, Сум. обл. ін-т післядиплом. пед. освіти. - Суми : [СОІППО], 2010. - 199 с. 16. Скрипка А. О. Шоу-технології як форма сочіальної комунікачії : автореф. дис. ... канд. сочіол. наук : 22.00.04 / Скрипка Анна Олегівна ; Харк. нач. ун-т ім. В. Н. Каразіна. - Харків, 2010. - 20 с. 17. Татаренко М. Г. Діяльність хореографа постановника в масових видовищних заходах / М. Г. Татаренко // Актуальні проблеми історії, теорії та практики художньої культури. - 2014. - Вип. 33. - С. 299-304. 18. Шоу «Огни Анатолии» и «Троя» в Туриии [Электронный ресурс]. - Режим доступа: http:// www.hierapolis-info.ru/ogni-anatolii-i-troya.html. 19. 9 декабря, балет «A6», спектакль «Сильнее страсти, больше, чем любовь...» [Электронный ресурс]. - Режим доступа: http://glavred.info/news/2007/11/29/120023-10. 